\title{
Natural Resources and Economic Outcomes
}

Forthcoming in Economic Evolution and Revolutions in Historical Time.

Edited by Paul Rhode. Stanford: Stanford University Press, 2010

\section{Karen Clay, Carnegie Mellon University and NBER}

\section{Introduction}

Why do some countries grow while others do not? This question is one of the most important in economics. Literally thousands of papers have been published on the topic. And it is of enormous policy significance, because the current understanding of the answer to this question affects the behavior of a variety of organizations including the World Bank, the International Monetary Fund, the Inter-American Development Bank and the Gates Foundation. Economists have recently begun to recognize that growth may well be path dependent. If it is, then understanding the current state of economic development is not sufficient to make policy. One needs to understand the historical evolution of the economy or economies in question. Only then can appropriate policies be formulated.

During the 1980s the United States experienced declining industrial competitiveness in the world economy. The reasons for the decline were hotly debated. As a means of informing the debate, Wright (1990) sought to understand the basis for American industrial success up to 1940. Economists tended to assume that America's advantage had always been technological. Among economic historians, some of whom had thought more carefully about the issue, the conventional wisdom was slightly more nuanced. Chandler $(1959,1977)$ argued that the build out of the transportation network during the nineteenth century in the United States allowed the creation of 
a single national market and that this market enabled the rise of large-scale manufacturing enterprises. Indeed, Atack, Haines, and Margo (in this volume) show that the building of railroads was not merely associated with the growth in manufacturing from 1850 to 1870 - it was causal. Goldin (1998) and Goldin and Katz (2008) show that the expansion of human capital also played an important role in the development of technology and industrial competitiveness more broadly. Technology was important, but it was intimately related to the emergence of national markets and the expansion of human capital. ${ }^{1}$

Wright (1990) showed that the conventional wisdom missed an important part of the story. "The most distinctive characteristic of U.S. manufacturing (from 1879 to 1940) was intensity in nonreproducible natural resources." ${ }^{2}$ Technology was certainly important, but it was a technology built on national markets and a specific class of natural resources. Wright addressed a second issue: "whether resource abundance reflected geological endowment or greater exploitation of geological potential." ${ }^{3}$ He argued that abundance built primarily on greater exploitation.

Wright's argument that American pre-war economic success was built on natural resources would shortly come into apparent conflict with a new literature that grew out of Sachs and Warner (1995). Sachs and Warner demonstrated that during the 1970s and 1980s countries with higher natural resource exports as a percentage of gross domestic product (GDP) experienced slower growth. The negative relationship between resources and growth came to be known as the resource curse. Beginning with Ross (2001), a parallel line of research in political science examined the negative effect of natural resources on political outcomes.

This paper reviews the state of these divergent and apparently conflicting literatures and then offers an interpretation that reconciles the findings. 


\section{American Industrial Growth}

American manufacturing exports burst onto the international scene in 1890s. Most American exports were producer goods, which dominated European goods in their quality and technical specifications. Although success was the culmination of a long historical process, American export growth was not particularly visible. That changed in the 1890s, when the United States became the largest producer of world industrial output. Shortly before 1913, the United States became the largest producer of industrial output per capita. Figure 1 shows the trajectories of industrial output per capita for three of the major industrial nations - the United States, the United Kingdom, and Germany. The United States' rapid growth in industrial output per capita seems to have been attributable to its overall comparative advantage in manufacturing. Broadberry (1993) documented that American labor productivity levels in manufacturing were roughly twice British levels over the period 1869 to 1989 . For much of this time, American labor productivity levels were also twice the German levels. Although much of the American output was consumed domestically, an increasing share was consumed abroad. Using data for 1937 for the United States and Britain, MacDougall (1951) found a positive relationship between relative labor productivity and relative exports. The United States exported more goods than Britain in segments in which it had high relative labor productivity.

To evaluate the sources of American success in the export market, Wright (1990) used data for 165 manufacturing industries in six years over the interval from 1879 to 1940 . He compared the inputs for industries for which the United States was a net importer with the inputs for industries for which it was a net exporter. Although the United States was exporting relatively more capital intensive and skill intensive goods than it was importing, Wright found that the differences were generally modest. At its peak the capital-labor ratio for exports relative to 
imports never exceeded 1.9, and the relative skill intensity as measured by average wages never exceeded 1.2.

For natural resources, the story was quite different. U.S. exports were much more natural resource intensive than its imports and relative resource intensity was generally rising from 1879 to 1914. In 1899, manufacturing exports were 3.5 times more natural resource intensive than imports in direct use and 1.7 times more intensive in direct and indirect use. ${ }^{4}$ In 1914 , the peak year for resource intensity, the ratios had risen to 7.4 for direct use and 2.4 for direct and indirect use. Further analysis showed that up to 1928, capital and natural resources were complements in net export performance. This finding was consistent with work by Cain and Patterson (1986), James (1983) and James and Skinner (1985) showing complementarities between capital and materials in production more broadly during the nineteenth and early twentieth centuries.

Wright linked the rise in natural resource intensity back to American success in world export markets. "This trend [in natural resource intensity] was growing both absolutely and relatively over precisely the historical period when the country was moving into a position of world industrial preeminence." ${ }^{5}$ Despite contemporary concerns regarding resource exhaustion, input prices in the United States were falling - not rising - following the Civil War. Falling prices reflected more intensive and efficient search for new deposits, greater efficiency in extraction of existing deposits, and falling costs of transportation. The United States dominated world production of nearly all economically important minerals.

Cheap steel was increasingly important as an export, both in its own right and as an input into machinery and automobiles. By 1913 steel, machinery, and automobiles accounted for 28 percent of American exports. Adding in petroleum products lifted the total to 38 percent of exports. $^{6}$ By 1929, steel, machinery, automobiles, and petroleum products accounted for 51 
percent of American exports. Irwin (2003) tied the surge in American exports in iron, steel, machinery, automobiles to the commercial exploitation of the Mesabi iron ore range. The availability of Mesabi ore caused domestic ore prices to fall by 50 percent. Lower ore prices made American exports increasingly competitive in the world market.

Erosion of the natural-resource-based success came with falling trade barriers after World War II. American industrial success continued as a result of its technological lead. Nelson and Wright (1992) argued that the post-war lead in high technology industries stemmed from "investments in higher education and in research and development, far surpassing the levels of other countries at that time.,"7 Erosion of the technological lead came as other countries made huge investments in higher education and research and development.

\section{Successful Exploitation of Natural Resources}

American industrial success was integrally related to its early and successful exploitation of its geological potential. In one of the only papers to examine how successful exploitation occurred, David and Wright (1997) identified several factors that facilitated rapid discovery and extraction of oil and minerals. These factors included public knowledge as embodied in geological surveys, mining education, an ethos of exploration, and incentives.

Individuals, states, and the federal government began to invest in geological surveys as early as the 1820s. In 1821, Stephen Van Rensselaer commissioned a survey of his vast landholdings, and he commissioned a survey of the route of the Erie Canal three years later. Responding to the discovery of gold in the state, North Carolina authorized a survey in 1823. The next year, South Carolina followed suit. A wave of surveys followed. Table 1 shows the dates of state geological surveys through 1870 and their costs. North Carolina appropriated $\$ 250$ per year for four years to defray the travel expenses of Denison Olmstead, a professor of Chemistry at University of 
North Carolina. South Carolina appropriated $\$ 500$ for Lardner Vanuxem, a professor at South Carolina College, to make "a geological and mineralogical tour during the recess of the college." ${ }^{\prime 8}$ The sums appropriated for later surveys appear to have been substantially higher than the amounts appropriated in North Carolina and South Carolina. In addition to expenses, later appropriations often covered salaries and printing of reports. The printing of reports - and more generally the dissemination of the geological information in the reports - was greatly aided by the fall in the cost of printing. ${ }^{9}$

State geological surveys served multiple purposes. Hendrickson (1961) finds: "In all states a major purpose was to locate, describe, and publicize such natural resources as salt and mineral springs, building stones, shales, clays, slates, coal, and ores. ... In some states- Maryland, Connecticut, Virginia, Georgia, Indiana, North Carolina, South Carolina and Massachusettsthere was a close tie between the demand for systems of internal improvements and the authorization of geological surveys." ${ }^{10}$ Surveys played important roles in the development of natural-resource based industries including copper and cement industry. ${ }^{11}$ The ties between internal improvement and geological surveys are also noteworthy, because they link the build out of the transportation infrastructure, the creation of the national market, and the development of natural resources.

Although bigger in scope, federal surveys tended to serve similar purposes. As Atack, Haines, and Margo (in this volume) discuss, the federal government made 59 surveys of roads, canals, and railroads between 1824 and 1838. Geological information was ancillary benefit of these surveys. During the 1830s federal surveys examined the mineral lands of Iowa, Wisconsin and Illinois. After a state survey in Michigan identified rich copper deposits on Chippewa land, the federal government purchased the land. Authorization of federal geological surveys of the 
Chippewa land and the area around Lake Superior followed shortly thereafter. In 1853 Congress appropriated $\$ 150,000$ for surveys to determine the best route from the Mississippi to the Pacific Ocean. The Corps of Topographical Engineers examined four potential routes and collected considerable scientific information. Transportation was also the impetus for the Geological Exploration of the Fortieth Parallel (the route of the Pacific railroad).

Oddly, individuals involved in oil exploration tended to dismiss geological surveys as only being relevant for minerals. This changed suddenly in 1911 with the discovery of oil in the Cushing Field in Oklahoma. The Cushing Field vividly demonstrated that oil was associated with anticlines, and in the west, locating the anticlines was a key to discovering new oil. Knowles (1959) writes: "The majority of discoveries during the next fifteen years resulted from the industry's sudden acceptance of petroleum geology as a science. ... Most of the large companies established permanent geological departments."12

American universities quickly saw the utility of establishing mining-related courses. In many universities, this built on existing programs in civil and other types of engineering. ${ }^{13}$ Civil engineering had long been part of the curriculum in military academies and a variety of other private and public universities. With the increasing importance of bridges, roads, canals, dams, and buildings during the nineteenth century, the value of systematic training in civil engineering became evident. The Morrill Acts of 1862 and 1890 facilitated the expansion of training of engineers by providing federal funding through grants of land to states to support the creation of new colleges and universities. Together the acts aided the establishment of more than 70 land grant colleges It was explicitly part of the colleges' mandate "to teach such branches of learning as are related to agriculture and the mechanic arts." 14 By 1882-1892, the largest share of graduates and non-graduates (46 and 39 percent) of land grant universities were in engineering. 
The share had shrunk slightly to 33 and 34 percent by 1919-1922, but engineers were still the largest group. ${ }^{15}$

Universities' actions were prompted by rich donors who had made their money in mining, state legislatures or demands by business. Columbia University was the leading American university, graduating nearly half of the mining engineers trained prior to 1892 . By the end of the nineteenth century, many other universities offered coursework in mining-related topics such as geology, mining, or metallurgy. For example, students could take mining-related courses at Case School, Harvard, Illinois, Lafayette, Lehigh, Massachusetts Institute of Technology, Michigan, Rensselaer, Stanford, Vanderbilt, Washington and Lee, Washington University, Wisconsin, and Yale. Many land grant universities had founded or were in the process of founding full-fledged mining schools. Many were in important mining states including Alabama, Arizona, California, Colorado, Iowa, Michigan, Missouri, Montana, New Mexico, Nevada, North Dakota, Ohio, South Dakota, Tennessee, and Utah. ${ }^{16}$

Because of their emphasis on practical training, American universities came to be preferred over European universities by students interested in studying mining. Before the Civil War, Americans interested in mining traveled to Europe for training. Of the European universities, the Bergakademie in Freiberg, Saxony and the École Nationale Supérieure des Mines in Paris, France were the most highly regarded. ${ }^{17}$ With the rise of mining coursework in American universities after the Civil War, most Americans stayed home.

The success of the American-style training is evident from the recruitment of Americantrained, rather than European-trained, engineers to operate foreign mining operations. ${ }^{18}$ A 1917 manpower census found that 28 percent of American mining engineers had worked abroad. Most had worked in Canada or Mexico, but many had worked elsewhere. These numbers are 
corroborated by evidence from the Colorado School of Mines. In a survey of alumni from 19001940, 64 percent had worked abroad at some point, 39 percent for several years.

Successful exploitation of mineral resources required more than just courses aimed at getting resources out of the ground. For the resulting oil and minerals to be put to use, they had to be translated into products by relatively skilled workers. ${ }^{19}$ Some skills were self-taught or learned on the job, but many skills were developed or refined in universities. American universities both public and private - offered courses in areas such as accounting, business, chemistry, metallurgy, civil engineering and mechanical engineering. This relatively sophisticated practical education was suited, by design, for big business. Although the numbers of university-trained students involved were small in absolute terms, their impact was large. Graduates with business backgrounds managed hundreds or even thousands of workers, while graduates with technical backgrounds made critical breakthroughs in products and processes.

David and Wright (1997) attributed the differences in exploration among the United States, Great Britain, and Australia largely to differences in beliefs. Americans believed that minerals were there, while the British, and to a greater extent the Australians, did not believe that minerals were there. The reliance on beliefs is somewhat unsatisfactory, because it begs the question of where they came from. If time establishment of a geological survey is indicative of beliefs, the Unite States fared poorly. The United States established a geological survey in 1879. By that point, Britain, Canada, India, and Australia all had had geological surveys for at least a decade. Certainly all of these governments expected to benefit from surveys, yet the United States was somehow uniquely successful in leveraging surveys and other information into natural resource development and industrialization. Beliefs may well have been linked to incentives. 
Incentives in the United States context arose from two factors - federal ownership of the public domain and the inclusion of mineral rights in the bundle of rights attached to land. The federal government permitted and even encouraged mining on the public domain, which covered much of the land from the Appalachians to the Pacific. Although individuals and corporations paid minimal or even no fees, they obtained relatively secure possessory rights. These conditions encouraged exploration and investment. Unlike some countries, where the central government explicitly reserved mineral rights, American property owners almost always held the mineral rights. Ownership gave them an incentive to develop their mineral holdings.

Clay and Wright (2005) used the California gold rush as a case study to better understand how property rights in mineral bearing land operated in practice. ${ }^{20}$ Many mining camp rules that emerged during the California gold rush were later codified by the federal government in the Mining Laws of 1866 and 1872. Thus, understanding the rules and their operation in practice is important for understanding incentives.

One of the key questions was: How secure were property rights? Since investment is related to the security of property rights, security has implications both for understanding the early stage of mining - which focused on placer mining - and later stages of mining - which focused on quartz mining. During the placer mining phase, levels of investment were generally low. Men progressed from panning for gold to more involved methods such as long toms and cradles. Long toms and cradles required some investment, but the investment could be protected by having one of the miners on site most of the time.

Property rights were insecure if miners were absent from their claims for extended periods of time. This often happened if miners left to prospect for gold elsewhere. Claim jumping seizing of a claim that was not currently in production - was a perennial issue. As population 
rose - and it rose extremely rapidly throughout 1849 and 1850 - newly arrived miners wanted to mine these claims. Strikingly, claim jumping was institutionalized in mining district constitutions through requirements on how claims must be marked, how many claims could be held, and how often the claim had to be worked for the use right to be maintained. Exceptions were often made for sickness and lack of water. However, to a first approximation, if the marking and work requirements were not met, others could begin mining the land. Conflict was inevitable, since newcomers often seized a claim first and asked questions later. Previous occupiers, having not met the work requirements, would also sometimes return and try to assert their claim by force. An unattractive variant on this was Americans simply using force to drive Mexican, Chinese, or other foreign-born miners off valuable claims.

Insecurity arose for somewhat different reasons also in riskier, larger scale projects. Damming and river turning projects were common, because they allowed direct access to placer gold in the river bottom. Here, one set of risks arose from the fact that other groups upstream or downstream would engage in similar projects, rendering the existing project infeasible. There was sometimes collateral damage for nearby placer claims, which were either flooded or lost access to customary sources of water. A second set of risks emerged from weather and engineering. Poor weather, particularly excessive rainfall, could sweep away partially completed projects or prevent their completion. Even under normal weather conditions, dams and other projects could fail due to poor design.

Quartz regions had their own issues. Claim jumping was less of an issue, because much of the work was done by corporations. But the apex rule and the possessory nature of claims still led to conflict. In her discussion of one of the most famous early quartz companies, the Mariposa Mining Company, Maureen Jung notes that "Like so many early mining companies, it was also 
plagued by lawsuits. Mariposa's legal disputes over mineral and water rights spanned a number of years and a variety of succeeding companies." ${ }^{21}$ The conflict was evident more generally in the number of cases reaching the California Supreme Court from 1850 to 1866. Most of these cases were brought by large quartz or water companies. Conflict of this type was not confined to California. According to Goldman (1981) in the Comstock, "Between 1860 and 1865, twelve major mining companies were involved in 245 different lawsuits, generating ten million dollars in litigation fees alone."22

The surprise is not that property rights were insecure, but that semi-secure property rights emerged in the midst of the chaos. As Zerbe and Anderson (2001) argued, cultural concepts of fairness led to the establishment of norms that were acceptable to American miners. These norms were often written down in mining district constitutions. The existence of culturally acceptable norms greatly facilitated the operation of the private-order institutions that governed property rights, by guaranteeing that miners would engage in first-party and second-party enforcement of property rights. In this context, first-party enforcement meant that many miners would choose to obey the norms. Second-party enforcement meant that miners would resolve disputes among themselves, through a combination of reference to norms and threats of punishment (usually violence) for violation of the norms.

However, norms in and of themselves were not sufficient to guarantee the successful operation of an institution. Most private-order institutions - including those that supported property rights in the gold rush - require the threat of third-party enforcement of property rights. That is, individuals who were not directly involved in the conflict (third parties) need to participate in the punishment in order for incentives to be maintained. Diaries, letters, and other historical accounts from the period offer some examples of third-party enforcement. In some 
instance, third-party enforcement was simply neighbors helping neighbors. In more complicated disputes, there would be a mining-district meeting or a smaller meeting in which the alcalde or some respected person within the mining district heard the two parties' arguments. Once a decision was made, the parties were expected to abide by the decision. If the loser(s) did not, third-party enforcement would, in principle, ensure compliance. In practice, the assembled miners or alcalde might well side with the stronger party, irrespective of the merits of the other party's claims. Or the decision simply might not be enforced. The question is why miners who were not directly involved in the conflict would take costly actions such as taking time away from mining to attend a camp meeting or risking physical injury by helping force recalcitrant miners off of a claim. Information transmission limited the functioning of third-party enforcement.

Taken together, the combination of public knowledge, education, the ethos of exploration, and incentives proved extremely powerful. Key stakeholders saw the value of investing in federal and state geological surveys and the education of mining engineers. Americans believed that minerals were around and so invested in finding them. Incentives were strong in the sense that federal and state governments did little to regulate, tax, or otherwise impede private exploration and development. All of these contributed to the early exploitation of American mineral resources.

\section{Natural Resources and Growth}

Were natural resources good or bad for economic growth? Wright (1990) argued that they were good for growth in industrial exports, while Sachs and Warner (1995) argued that they were bad for economic growth. Figure 2 illustrates Sachs and Warner's basic empirical relationship. Natural resource exports as a share of GDP in 1970 was negatively related to growth over the 
next two decades in a large sample of countries. This relationship holds in a regression framework across a variety of specifications.

Sachs and Warner evaluated a number of hypotheses for the negative effect of resources on growth, including rent seeking and corruption, protectionism, the pricing of tradable and nontradable goods, and shifts in labor demand from learning by doing sectors. They found limited evidence of natural resources affecting growth through bureaucratic quality. The evidence was stronger for protectionism. In most economies, resource abundance negatively affects the manufacturing sector, which leads to a protectionist response. In a few oil countries, this does not hold. Overall, they found evidence of a U-shaped effect. Other effects were small.

One might wonder whether the United States was in some way unique, but evidence suggests that states have also suffered from resource curses. Goldberg, Wibbels, and Mvukiyehe (2008) conduct an analysis similar to Sachs and Warner for the American states for 1929-2002. They find negative relationships between natural resources and per capita income, a measure of very long run growth, and between natural resources and growth. Figure 3 illustrates the relationship between natural resources and per capita income.

Why do the two types of analysis yield different answers? Part of the difference arises because the papers study different numbers of economies, different time periods, and different outcomes. Wright studied the United States (national) economy from 1879 to 1940, and most of the effects he finds were for the period up to 1928. Sachs and Warner studied growth in 97 countries from 1971 to 1989 and Goldberg, Wibbels, and Mvukiyehe studied growth in the American states from 1929 to 2002. Wright investigated differences in inputs into American exports and imports, while Sachs and Warner and Goldberg, Wibbels, and Mvukiyehe examined the effect of natural resources exports on country-level and state-level economic growth. Yet 
questions remain as to why these papers reach such very different conclusions. I will return to these differences at the end of the paper.

In light of this conflict and to better understand the resource curse, subsequent papers investigated the mechanisms through which natural resources acted on growth. Mehlum, Moene, and Torvik (2006) studied growth over a longer period 1965-1990 using the sample of 87 countries from Sachs and Warner (1997b). They found that the effect of resources on growth was mediated by institutions. In countries where resource exports represented more than 10 percent of GDP, the resource curse only held for the countries with low-quality institutions. In countries with low-quality institutions, rent seeking and production were competing activities, while in countries with the high-quality institutions, rent seeking and production were complementary activities. Robinson, Torvik, and Verdier (2006) modeled the interaction of natural resource growth with political policies. Based on the model and empirical analysis, they found that institutions were important mediators of the effects of resource booms. Subsequent work by Yang (2008) argued that policies and not institutions affected outcomes. Countries with good institutions could have bad policies and the reverse.

Other papers questioned Sachs and Warner's measure of natural resources. The measure used by Sachs and Warner (1995) and later scholars was a measure of export dependency and not endowment or production. New measures of resource endowments from Brunnschweiler (2008) suggest that endowments and growth are positively related. The basic empirical relationships between endowments and growth are illustrated in Figure 4.

The literature has a number of interrelated deficits, including the short period over which growth is typically measured, the reliance on cross-sectional identification of effects, and the cursory examination of institutions and policies. Ideally, the period of study would extend back 
into the nineteenth century. With a panel data set, time-series and cross-sectional estimates of the effects could be constructed and compared. One could also test whether the relationships between natural resources and economic growth have shifted over time. For example, the observed relationships could be examined for the period 1879-1928, the period in which Wright (1990) found strong positive effects of natural resources on American exports. This paper is not the first to remark on the short periods over which growth economists examine outcomes. In his 1996 paper, Why, Indeed, in America? Paul Romer noted the lack of dialog between the economic history literature and the growth literature and the short horizon that most growth economists consider. More than ten years later the situation remains the same.

A more detailed examination of political institutions and policies related to public knowledge, education, incentives and technology can clarify their importance. Drawing on a number of current and historical case studies, Wright and Czelusta (2004) argued that policies are critical determinants of the effects of natural resources on growth. Countries with policies that have focused on exploration, technology, and knowledge-related investments have been successful. Similarly bad policies or institutions can lead to undesirable outcomes such as rentseeking and corruption. "If minerals are conceived as fixed stocks, and mineral abundance as a "windfall" unconnected to past investment, then the problem becomes one of divvying up the bounty rather than creating more bounty."23 Subsequent work by Brunnschweiler and Bulte (2008) explored these themes further. They conclude "Contrary to the paradoxical result that resource abundant countries tend to invite rent seeking and therefore suffer from worse institutions, we find that countries with certain institutional designs may fail to industrialize and failing to develop significant non-resource sectors may make them dependent on primary sector extraction." 24 This line of work represents a promising start, but there is all too little of it. 


\section{Natural Resources and Political Outcomes}

Ross (2001) began a line of research on natural resources and economic outcomes that very much parallels the work in economics. Using data for in 113 countries over the period 19711997, he examined the relationship between oil exports as a percentage of GDP the Polity scores of countries. ${ }^{25}$ Polity scores capture the degree to which regimes are authoritarian and democratic, with higher values indicating greater levels of democracy. He found that countries with high levels of natural resource exports were less likely to be democratic.

Goldberg, Wibbels, and Mvukiyehe (2008) took a very similar approach, but examined the American states. They showed that natural resource dependence was associated with less competitive state politics. Their work also suggests a mechanism through which resource dependence acts on politics. Because tax revenue is easier to generate in states with high levels of resource dependence, political elites can take actions that preserve their political power at lower cost. Thus, natural resources have a conservative influence on the political structure.

Later authors found that the sign of the effect depended on a variety of factors. For example, Jones Luong and Weinthal (2006) found that private ownership of the oil industry was good for democracy and state ownership was bad for democracy. Analysis by Dunning (2008) showed that the effect was dependent on the size of the economic rents from the natural resource and the structure of the economic elite. Herb (2005) used a different measure of natural resources - the percentage of government revenue from resources. This weakened the relationship between resources and democracy. Other plausible measures such as windfall profits from oil or minerals as a fraction of GDP or per capita generate no association at all (Ross 2006). And as Haber (2006) notes, one needs to be concerned about reverse causality. Authoritarian regimes may be 
bad for GDP, which would account for the negative association in any measure of natural resources that is computed as a share of GDP.

In contrast to the economics literature, the political science literature has recently begun to move beyond cross-sectional identification. Haber and Menaldo (2009) built a data set that allows for time-series identification of the effects of natural resources on political outcomes as measured by the Polity score. ${ }^{26}$ Using a variety of archival and contemporary sources, they constructed extended series of the percentage of government revenue from oil or minerals for seventeen countries. Like the use of endowments rather the exports in the growth context, government revenue from natural resources appears to be a more appropriate independent variable than natural resource exports as a share of GDP in the political context. All seventeen countries had average natural resource exports as a share of GDP of at least 6 percent, and so were significant exporters. Haber and Menaldo find no relationship between the percentage of government revenue from resources and the Polity score. They also re-analyze the conventional data sets using time-series techniques. No effect is found there either. What they do find is that the conventional cross-sectional relationships are sensitive to a variety of factors including how one deals with outliers.

\section{Understanding Natural Resources, Growth and Political Outcomes}

I want to advance a historical framework within which the empirical patterns for natural resources, growth and political outcomes can be reconciled. Suppose countries with strong political institutions were the first to develop their natural resources. And for these countries, natural resources facilitated growth. Although some countries may have experienced more success than others for a variety of reasons, natural resources were often a complement to manufacturing. One reason was that high transportation costs and limited functioning of world 
markets made exporting most natural resources without further processing or value added unattractive. Countries without strong political institutions and some manufacturing or processing capability simply did not develop their natural resource base. Eventually, particularly after World War II, transportation costs fell and world commodity markets expanded. This made it profitable for many more countries to develop their natural resources, often with the aid of large multinational corporations. But most of the countries with large and relatively untapped natural resource bases were precisely those countries with weak political institutions or limited manufacturing or processing capability. To be sure, there were some exceptions. North Sea Oil discoveries in Britain and Norway would certainly be examples. But the vast majority of countries were negatively selected. This did not necessarily doom them. Some countries began to invest in education, technology, and processing. Many other countries experienced turmoil, because newfound wealth, volatility in world commodity markets, and weak institutions proved to be an unfortunate combination. Hence, we observe a resource curse.

A similar relationship may hold for the American states, although possibly for slightly different reasons. Western states may or may not have had weaker political institutions initially, but they certainly had fewer settlers. Low density and late settlement led to later discovery and development of resources. By the time they were discovered, transportation costs within the United States had already fallen dramatically. As a result, resources were transported to eastern and midwestern states that already had manufacturing capability. Thus, resources may have been a curse at the state level, yet simultaneously have been a benefit at the national level.

This hypothesis is in principle testable at both the country and state level. While testing it is beyond the scope of this paper, the hypothesis suggests that bringing together natural resource, growth, and political data over a long time span would be a fruitful exercise. One would need to 
define what strong political institutions might mean: security of property rights, a democratic regime, the competitiveness of elections, a lack of corruption or perhaps all of the above.

Measures of some of these variables exist for many countries from 1800 on and most American states beginning around 1870. Similarly data on growth and natural resources exist or could be constructed for a substantial number of countries back to 1900 or earlier. Analysis of these panels could inform current debates regarding the interrelation among politics, resources, and growth. Given the importance of the issue, such an endeavor seems worthwhile. 
Figure 1: Industrial Output Per Capita (UK in $1900=100)$

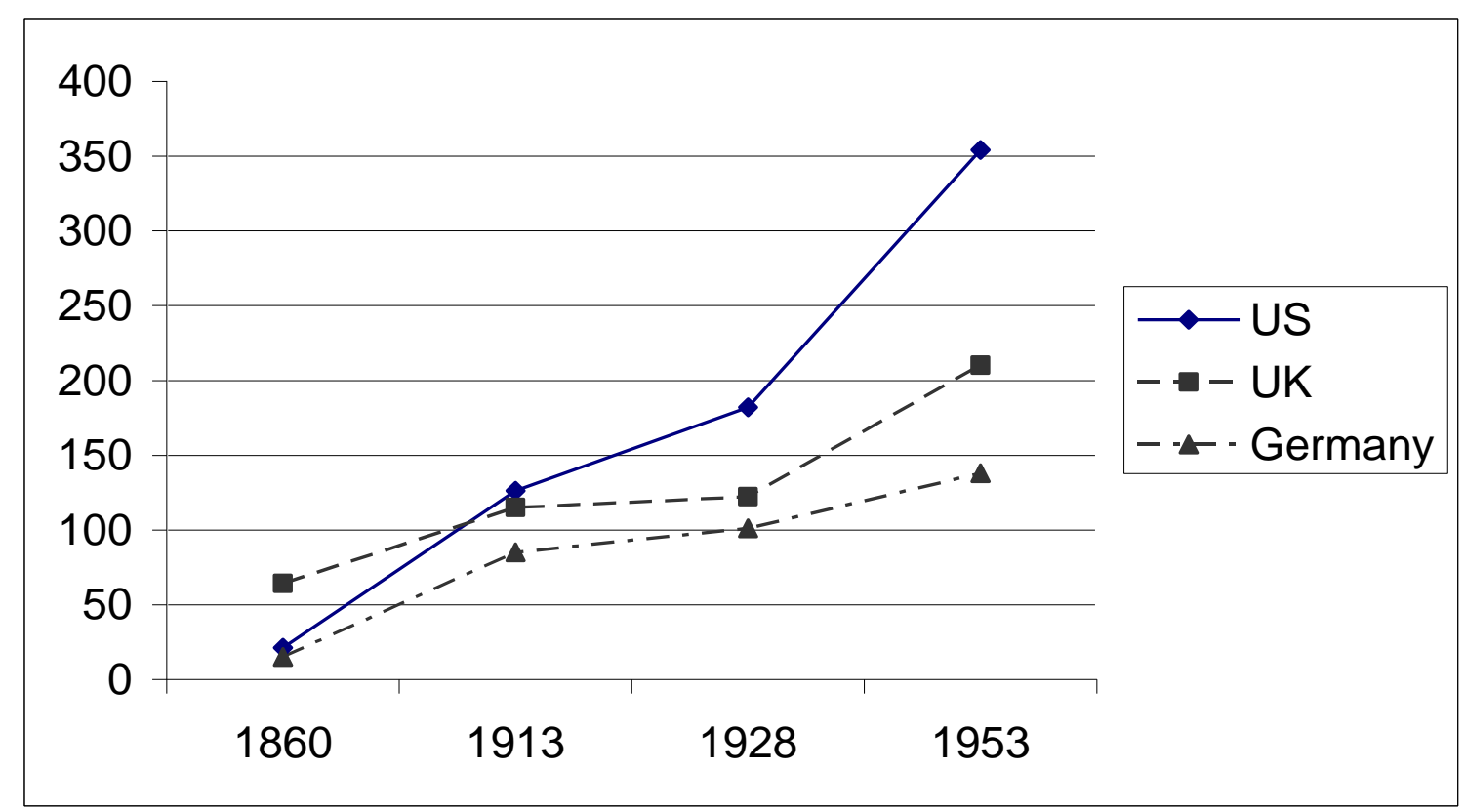

Sources: Data from Bairoch (1982) reprinted in O’Brien (1998), Table 4, p. 12. 
Figure 2: Natural Resource Exports and Growth

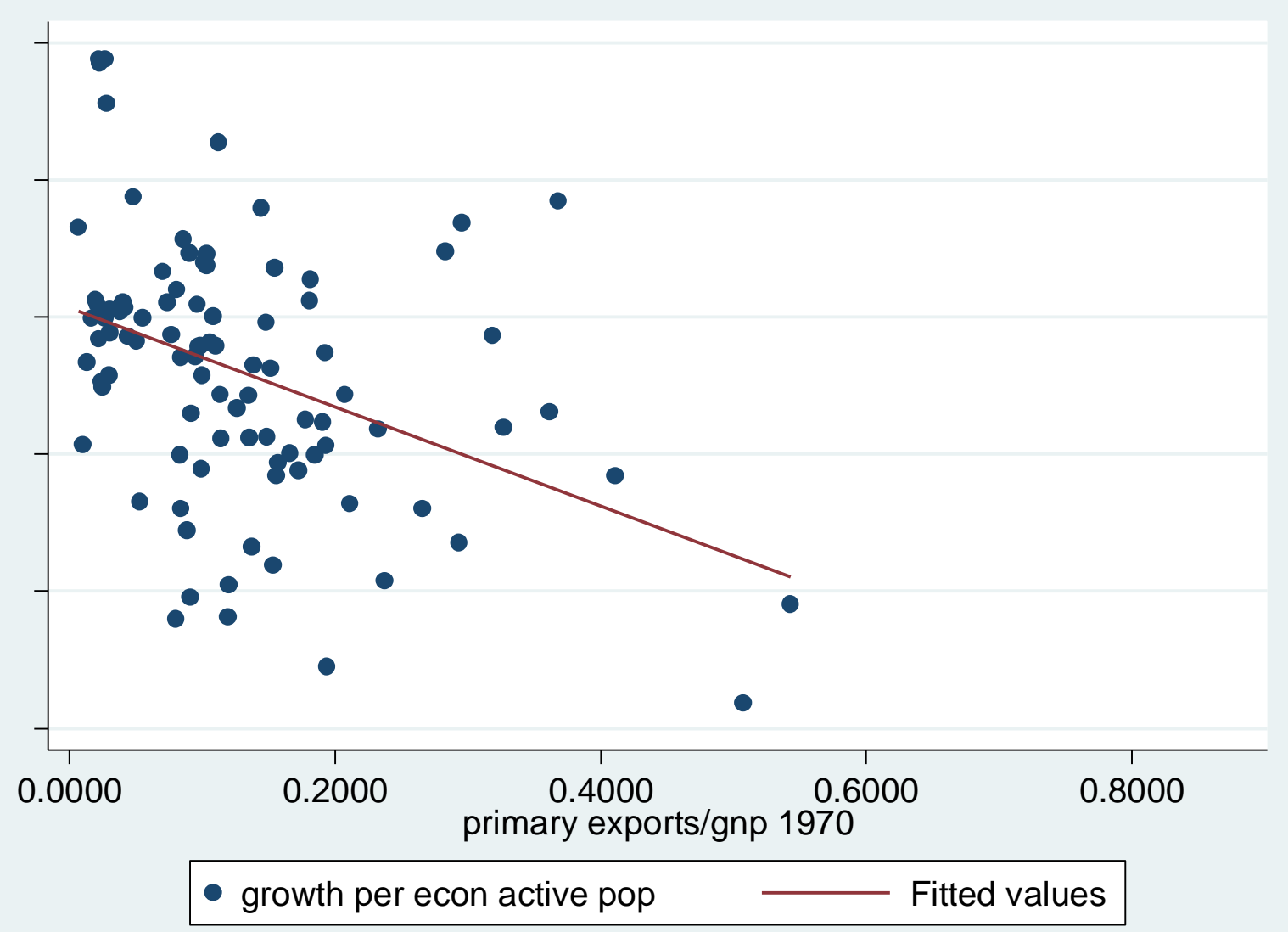

Sources: Created from original data for Sachs and Warner (1997a) available at http://www.cid.harvard.edu/ciddata/ciddata.html . 
Figure 3: Per Capita Income and Oil and Coal Production as a share of GDP in American States

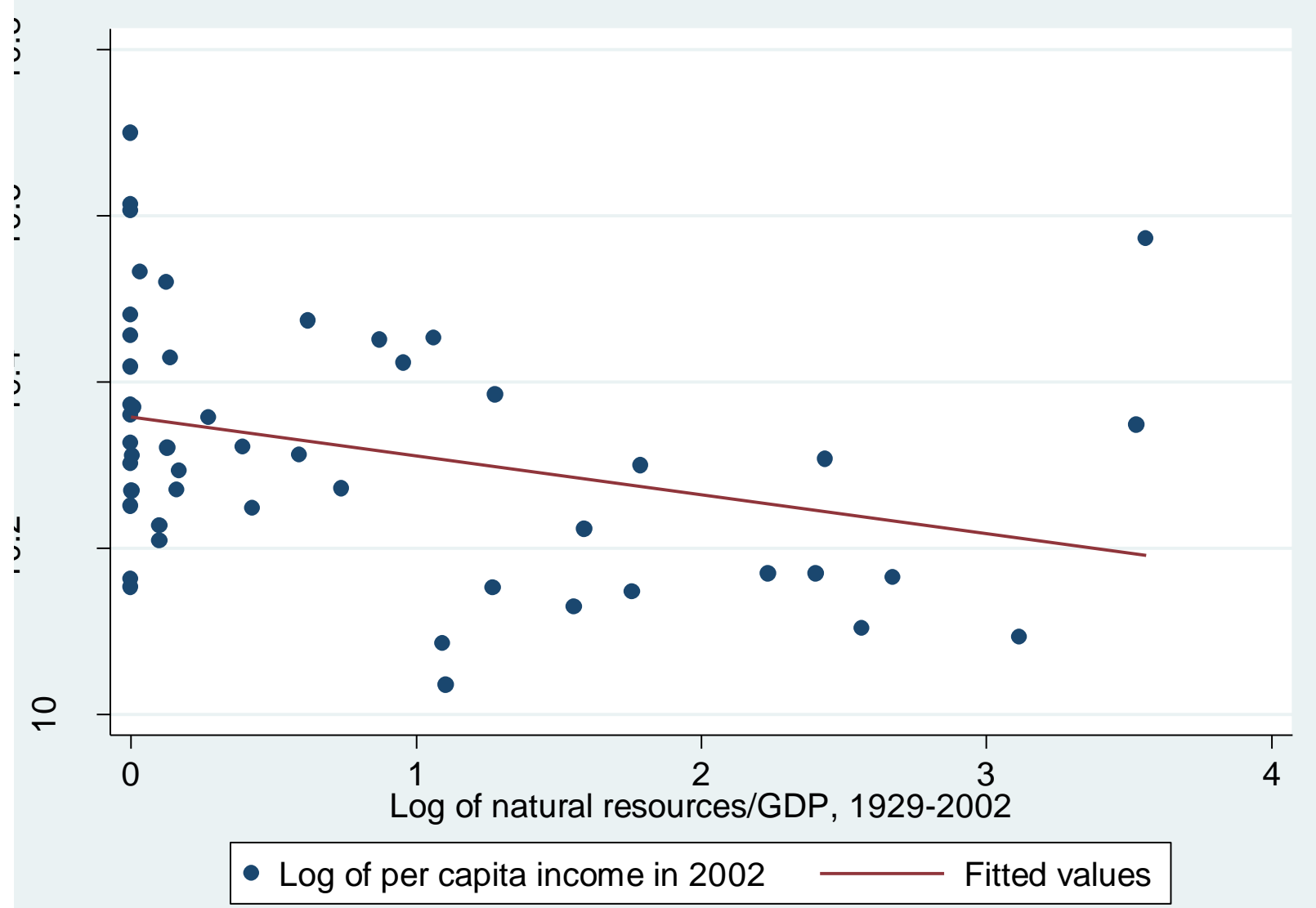

Sources: Created from original data for Goldberg, Wibbels, and Mvukiyehe (2008), p. 492,

Figure 4. The authors kindly shared their data. 
Figure 4: Natural Resource Abundance and Growth

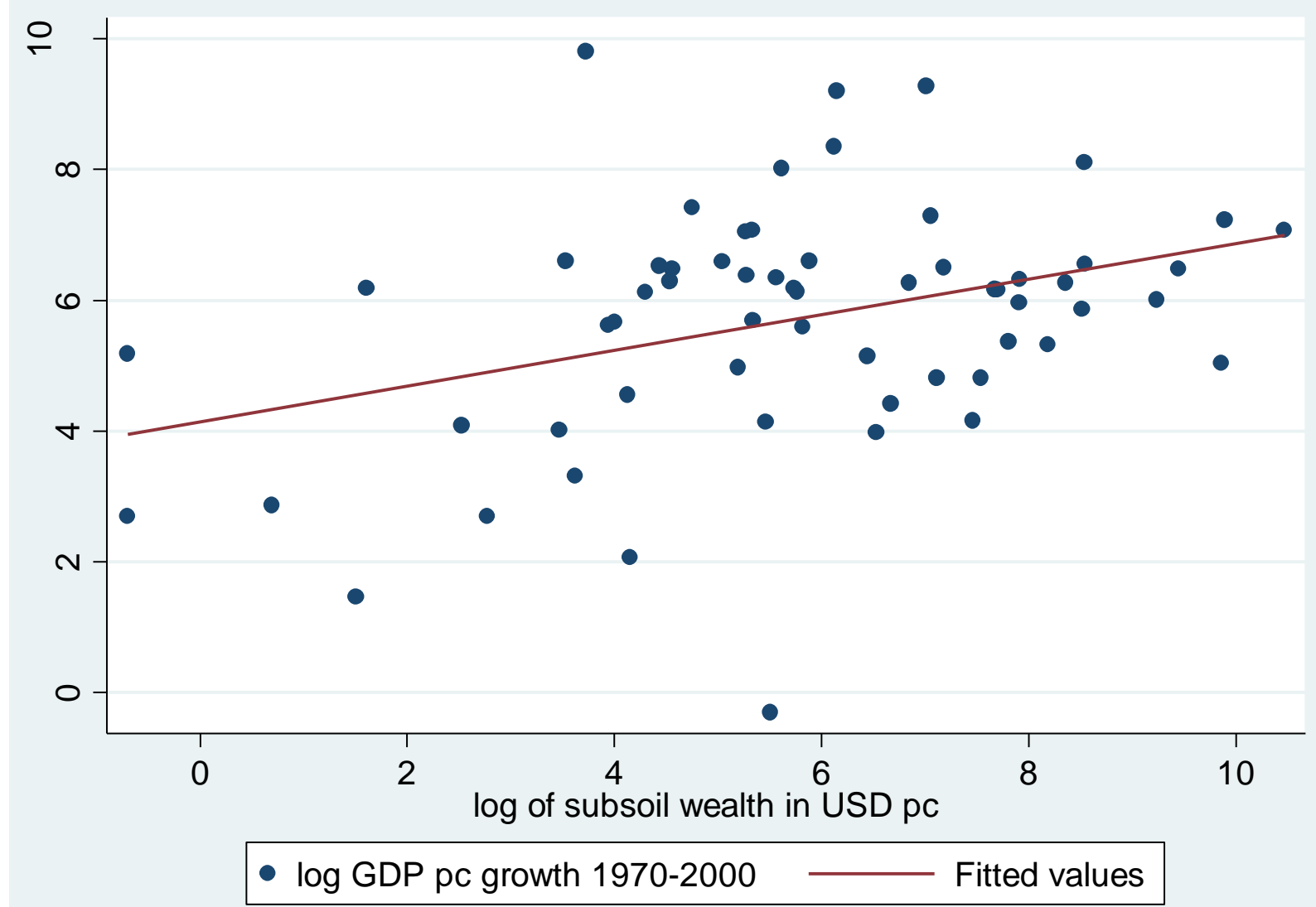

Sources: Created from original data for Brunnschweiler (2008), p. 402, Figure 1. The author kindly shared her data. 
Table 1: Dates of State Geological Surveys to 1870

\begin{tabular}{|c|c|c|c|}
\hline State & Statehood & Survey & Survey Appropriation \\
\hline \multicolumn{4}{|l|}{ Northeast } \\
\hline Connecticut & 1788 & 1835 & \\
\hline Maine & 1820 & 1836 & 8,000 \\
\hline Massachusetts & 1788 & 1830 & 2,030 \\
\hline New Hampshire & 1788 & 1839 & \\
\hline New Jersey & 1787 & 1833 & \\
\hline New York & 1788 & 1836 & \\
\hline Pennsylvania & 1787 & 1836 & \\
\hline Rhode Island & 1790 & 1839 & 2,000 \\
\hline Vermont & 1791 & 1845 & \\
\hline \multicolumn{4}{|l|}{ South } \\
\hline Alabama & 1819 & 1848 & \\
\hline Delaware & 1787 & 1837 & \\
\hline Georgia & 1788 & 1836 & \\
\hline Kentucky & 1792 & 1838 & \\
\hline Louisiana & 1812 & 1869 & \\
\hline Maryland & 1788 & 1833 & \\
\hline Mississippi & 1817 & 1850 & \\
\hline North Carolina & 1789 & 1823 & 1,000 \\
\hline South Carolina & 1788 & 1824 & 500 \\
\hline
\end{tabular}




\begin{tabular}{|l|c|c|l|}
\hline Tennessee & 1796 & 1831 & \\
\hline Texas & 1845 & 1858 & \\
\hline Virginia & 1788 & 1836 & \\
\hline Midwest and West & & & \\
\hline California & 1850 & 1853 & \\
\hline Illinois & 1818 & 1851 & \\
\hline Indiana & 1816 & 1837 & \\
\hline Iowa & 1846 & 1855 & \\
\hline Kansas & 1861 & 1864 & \\
\hline Michigan & 1837 & 1837 & \\
\hline Minnesota & 1858 & 1865 & \\
\hline Missouri & 1821 & 1853 & \\
\hline Ohio & 1803 & 1836 & \\
\hline Wisconsin & & & \\
\hline
\end{tabular}

Sources: From Hendrickson (1961), footnote 18 and Merrill (1906). All dates are the beginning of the first state survey. Cost estimates are from Merrill (1906). 


\section{$\underline{\text { References }}$}

Atack, Jeremy, Michael Haines, and Robert Margo, this volume. "Railroads and the Rise of the Factory: Evidence for the United States, 1850-1870.” In Paul Rhode, Joshua Rosenbloom, and David Weiman (eds.). Economic Evolution and Revolution in Historical Time. Stanford: Stanford University Press.

Bairoch, Paul. "International Industrialization Levels from 1750 to 1980." Reprinted in Industrialisation: Critical Perspectives on the World Economy, 1998. Edited by Patrick Karl O'Brien. Berlin: Walter de Gruyter.

Bowman, Mary Jean. 1962. "The Land-Grant Colleges and Universities in Human-Resource Development.” Journal of Economic History, 22: 523-546.

Broadberry, Stephen. 1993. "Manufacturing and the Convergence Hypothesis: What the LongRun Data Show.” Journal of Economic History, 53: 772-795.

Brunnschweiler, Christa. 2008. "Cursing the Blessings? Natural Resource Abundance, Institutions, and Economic Growth.” World Development, 36: 399-419.

Brunnschweiler, Christa and Erwin Bulte. 2008. "The Resource Curve Revisited and Revised: A Tale of Paradoxes and Red Herrings." Journal of Environmental Economics and Management, 55: 248-264. 
Cain, Louis and Donald Patterson. 1986. "Biased Technical Change, Scale, and Factor

Substitution in American Industry, 1850-1919.” Journal of Economic History, 46: 153-164.

Chandler, Alfred D. 1959. "The Beginnings of "Big Business" in American Industry." The

Business History Review, 33:1-31.

Chandler, Alfred D. 1977. The Visible Hand: The Managerial Revolution in American Business. Cambridge: The Belknap Press of Harvard University Press.

Clay, Karen and Gavin Wright. 2005. “Order without law? Property rights during the California gold rush," Explorations in Economic History, vol. 42(2), pages 155-183, April.

Carlson, Leonard, this volume. "Two Cheers for U.S. Indian Reservations: United States Indian Policy as Compared to Australian Policy Towards Aboriginal Peoples." In Paul Rhode, Joshua Rosenbloom, and David Weiman (eds.). Economic Evolution and Revolution in Historical Time. Stanford: Stanford University Press.

David, Paul A. and Gavin Wright. 1997. "Increasing Returns and the Genesis of American Resource Abundance," Industrial and Corporate Change, 6: 203-45.

Davis, Lance and Robert Cull. 2000. "International capital movements, domestic capital markets, and American economic growth, 1820-1914." In Stanley Engerman and Robert E. Gallman eds, 
The Cambridge Economic History of the United States, Volume II, Cambridge: Cambridge University Press.

Dunning, Thad. 2008. Crude Democracy: Natural Resource Wealth and Political

Regimes. New York: Cambridge University Press.

Engerman, Stanley and Kenneth Sokoloff. 2000. "Technology and Industrialization, 1790-1914.”

In Stanley Engerman and Robert E. Gallman eds, The Cambridge Economic History of the

United States, Volume II, Cambridge: Cambridge University Press.

Goldberg, Ellis, Eric Wibbels, and Eric Mvukiyehe. 2008. "Lessons from Strange Cases:

Democracy, Development, and the Resource Curse in the U.S. States.” Comparative Political Studies, 41: 477-514.

Goldin, Claudia. 1998. “America's Graduation from High School: The Evolution and Spread of Secondary Schooling in the Twentieth Century." Journal of Economic History, 58: 345-374.

Goldin, Claudia and Lawrence Katz. 2008. The Race between Education and Technology. Cambridge: Harvard University Press.

Goldman, Marion. 1981. Gold Diggers and Silver Miners: Prostitution and Social Life on the Comstock Lode. Ann Arbor: University of Michigan. 
Grantham, George, this volume. "Science and its Transactions Cost: The Evolution of an Implicit Contract.” In Paul Rhode, Joshua Rosenbloom, and David Weiman (eds.). Economic Evolution and Revolution in Historical Time. Stanford: Stanford University Press.

Haber, Stephen. 2006. “Authoritarian Government.” In Barry Weingast and Donald

Wittman eds., The Oxford Handbook of Political Economy. Oxford: Oxford University Press.

Haber, Stephen and Victor Menaldo. 2009. "Do Natural Resources Fuel Authoritarianism? A Reappraisal of the Resource Curse.” Working Paper.

Hendrickson, Walter B. 1961. "Nineteenth-Century State Geological Surveys: Early Government Support of Science.” Isis, 52: 357-371.

Herb, Michael. 2005. "No Representation without Taxation? Rents, Development, and Democracy." Comparative Politics 37: 297-317.

Irwin, Douglas. 2003. "Explaining America's Surge in Manufactured Exports, 1880-1913.” Review of Economics and Statistics, 85: 364-376.

James, John. 1983. "Structural Change in American Manufacturing, 1850-1890.” Journal of Economic History, 43: 433-459. 
James, John and Jonathan Skinner. 1985. "The Resolution of the Labor-Scarcity Paradox." Journal of Economic History, 45: 513-540.

Jones Luong, Pauline and Erica Weinthal. 2006. "Rethinking the Resource Curse: Ownership Structure, Institutional Capacity, and Domestic Constraints." Annual Review of Political Science 9: 241-63.

Jung, Maureen A. 1999. "Capitalism Comes to the Diggings: From Gold-Rush Adventure to Corporate Enterprise.” In James J. Rawls and Richard L. Orsi (eds), A Golden State: Mining and Economic Development in Gold Rush California.

Lamoreaux, Naomi. 2000. "Entrepreneurship, Business Organization, and Economic Concentration." In Stanley Engerman and Robert E. Gallman eds, The Cambridge Economic History of the United States, Volume II, Cambridge: Cambridge University Press.

Knowles, Ruth Sheldon. 1959, 1978. The Greatest Gamblers: The Epic of American Oil Exploration. Norman: University of Oklahoma.

MacDougall, G. D. A. 1951. "British and American Exports: A Study Suggested by the Theory of Comparative Costs, Part I.” Economic Journal, 61: 697-724.

Merrill, George Perkins. 1906. Contributions to the History of American Geology. Washington, D. C.: Government Printing Office. 
Mehlum, Halvor, Karl Moene, and Ragnar Torvik. 2006. "Institutions and the Resource Curse." Economic Journal, 116: 1-20.

Nelson, Richard R. and Gavin Wright. 1992. "The Rise and Fall of American Technological Leadership: The Postwar Era in Historical Perspective,” Journal of Economic Literature, vol. 30(4):1931-64.

Olmstead, Alan and Paul Rhode, this volume. "Productivity Growth and the Regional Dynamics of Antebellum Southern Development.” In Paul Rhode, Joshua Rosenbloom, and David Weiman (eds.). Economic Evolution and Revolution in Historical Time. Stanford: Stanford University Press.

Prentice, David. 2006. "A Re-Examination of the Origins of American Industrial Success." Working Paper.

Read, Thomas. 1941. The Development of Mining Industry Education in the United States. New York, The American Institute of Mining and Metallurgical Engineers.

Reynolds, Terry. 1992. "The Education of Engineers in America before the Morrill Act of 1862." History of Education Quarterly, 32: 459-482. 
Robinson, James, Ragnar Torvik, and Thierry Verdier. 2006. "Political Foundations of the Resource Curse." Journal of Development Economics, 79: 447-468.

Romer, Paul. 1996. "Why, Indeed, in America? Theory, History, and the Origins of Modern Economic Growth.” American Economic Review, 86: 202-206.

Ross, Michael. 2001. “Does Oil Hinder Democracy?” World Politics 53: 325-61.

Ross, Michael. 2006. “A Closer Look at Oil, Diamonds, and Civil War.” Annual Review of Political Science 9: 265-300.

Sachs, Jeffrey and Andrew Warner. 1995. "Natural Resource Abundance and Economic Growth.” NBER Working Paper \#5398.

Sachs, Jeffrey and Andrew Warner. 1997a. "Natural Resource Abundance and Economic Growth.” CID Working Paper

Sachs, Jeffrey and Andrew Warner. 1997b. "Sources of Slow Growth in African Economies." Journal of African Economies, 6: 335-376.

Thelin, John. 2004. A History of American Higher Education. Baltimore: Johns Hopkins University Press. 
Wright, Gavin, 1978. The Political Economy of the Cotton South: Households, Markets, and Wealth in the Nineteenth Century. New York: Norton.

Wright, Gavin, 1990. “The Origins of American Industrial Success, 1879-1940," American

Economic Review, vol. 80(4), pages 651-68, September.

Wright, Gavin and Jesse Czelusta, 2004. "Why Economies Slow: The Myth of the Resource Curse," Challenge, vol. 47(2), pages 6-38, March.

Yang, Benhua. 2008. "Resource Curse: The Role of Institutions versus Policies.” Applied Economics Letters.

Zerbe, Richard O. and C. Leigh Anderson. 2001. "Culture and Fairness in the Development of Institutions in the California Gold Fields." Journal of Economic History. 61: 114-143. 
${ }^{1}$ See Engerman and Sokoloff (2000), Lamoreaux (2000) and Davis and Cull (2000) for overviews of the economic history literature on specific part of this story. Romer (1996) offers a brief synthesis of the literature from a growth perspective.

${ }^{2}$ Wright (1990), p. 651.

${ }^{3}$ Wright (1990), p. 651.

${ }^{4}$ See Wright (1990), Table 3.

${ }^{5}$ Wright (1990), p. 658. (Emphasis in original.)

${ }^{6}$ See Wright (1990), Table 6.

${ }^{7}$ Nelson and Wright (1992), p. 1960.

${ }^{8}$ Quoted in Hendrickson (1961), p. 359.

${ }^{9}$ See Grantham (this volume). The fall in printing costs was also facilitating dissemination of information in farming, including cotton production. See Olmstead and Rhode (this volume). Indeed, there are some interesting parallels between the exploitation of point source resources such as minerals and more diffuse resources such as land capable of growing cash export crops such as cotton. For discussion of the South's exploitation of its comparative advantage in cotton, see Wright (1978).

${ }^{10}$ Hendrickson (1961), p. 361.

${ }^{11}$ David and Wright (1997) and Prentice (2006).

${ }^{12}$ Knowles (1959), p. 149.

${ }^{13}$ This draws on Reynolds (1992) and Thelin (2004).

${ }^{14}$ Morrill Act of 1862.7 U.S.C. 301 et seq. 
${ }^{15}$ See Bowman (1962), especially Tables 2 and 3.

${ }^{16}$ See Read (1941).

${ }^{17}$ Scientific research had only recently come to be located in universities. See Grantham (this volume).

${ }^{18}$ See David and Wright (1997) for a discussion of changes in technical training and the experience of U.S. mining engineers and chemists abroad.

${ }^{19}$ See Goldin and Katz (2008).

${ }^{20}$ See Carlson (this volume) for a discussion of the effects of the gold rush on Native Americans in California.

${ }^{21}$ Jung (1999), pp. 63-65.

${ }^{22}$ Goldman (1981) citing Spence (1970).

${ }^{23}$ Wright and Czelusta (2004), p. 36.

${ }^{24}$ Brunnschweiler and Bulte (2008), p. 250.

${ }^{25}$ Ross's polity score is derived from the Polity 98 data set compiled by Gurr and Jaggers, which scores countries on a $0-10$ scale for autocracy and level of democracy. The autocracy measure is subtracted from the democracy measure and rescaled to 0-10.

${ }^{26}$ Haber and Menaldo use the Polity IV dataset, a later version of the dataset used by Ross (2001). They use the Combined Polity 2 score, which "measures the competitiveness of political participation, the openness and competitiveness of executive recruitment, and the constraints on the chief executive." Haber and Menaldo (2009), p. 10. 